\title{
Analisis Kesalahan Mahasiswa Semester V dalam Mengerjakan Soal Pengantar Analisis Real
}

\author{
Hodiyanto \\ Program Studi Pendidikan Matematika, IKIP PGRI Pontianak, Jalan Ampera No 8 \\ Pontianak \\ Email: haudy7878@yahoo.com
}

\begin{abstract}
Abstrak
Tujuan penelitian ini adalah untuk mengetahui: (1) Kesalahan yang dilakukan oleh mahasiswa semester V Program Studi Pendidikan Matematika dalam mengerjakan soal pengantar analisis real. (2) Penyebab kesalahan yang dilakukan oleh mahasiswa semester $\checkmark$ Program Studi Pendidikan Matematika dalam mengerjakan soal pengantar analisis real. Metode penelitian ini menggunakan metode diskriptif. Teknik pengumpul data yang digunakan wawancara berbasis tugas dan pengukuran, sedangkan alat pengumpul datanya lembar wawancara dan tes. Teknik analisis data yang digunakan adalah reduksi data, penyajian data, dan penarikan kesimpulan. Berdasarkan hasil analisis jawaban siswa dan wawancara diperoleh bahwa: (1) Mahasiswa melakukan kesalahan: memberikan pemisalan, kesimpulan yang diberikan di langkah-langkah jawaban, menentukan himpunan penyelesaian pertidaksamaan kuadrat, dan menentukan infimum dan suremum (2) Penyebab kesalahan mahasiswa adalah mahasiswa kurang teliti dalam melakukan pembuktian, terburu-buru dalam menyelesaikan soal, jarang menyelesaikan soal-soal yang memiliki kesulitan tingkat tinggi atau soal-soal high order thinking, mahasiswa lemah dalam kemampaun pembuktian matematis, dan mahasiswa juga tidak terbiasa dalam menjawab soal dengan pola yang terstruktur.
\end{abstract}

Kata Kunci: Kesalahan, Pengantar Analisis Real, Penyebab Kesalahan

\begin{abstract}
The purpose of this study was to know: (1) Errors made by $V$ semester students of Mathematics Education in working on the test of real analysis introduction. (2) Causes of errors done by student in working on the test of introduction of real analysis. This research method used descriptive method. Techniques to gather the data are task-based interview and measurement and data collection tools are interview sheet and test. Data analysis techniques used are data reduction, data display, and conclusion drawing. Based on analysis of student answers and interviews showed that: (1) Students make errors: provide an option, conclusions given in the answer steps, determine the set of quadratic inequalities settlement, and determine infimum and suremum (2) The causes of the student error in working on the test of introduction of real analysis are: Students are less in doing the proof, rush in solving problems, rarely solve problems that have high difficulty or high order thinking tests, students are weak in the ability of mathematical proof, and students are also not accustomed in answering questions with a structured pattern.
\end{abstract}

Keywords: Error, Introduction to Real Analysis, Cause of Error 


\section{PENDAHULUAN}

Matematika adalah salah satu mata pelajaran yang erat hubungannya dengan simbol dan variabel dan matematika juga memiliki konsep yang abstrak. Selain itu, menurut (Shadiq 2014: 69) matematika dikenal sebagai mata pelajaran yang bersifat deduktif aksiomatif. Hal ini berarti bahwa suatu suatu pengetahuan baru merupakan akibat dari pernyataan lain yang telah diterima kebenarannya seperti postulat atau aksioma mauun teorema lain yang telah dibuktikan kebenarannya seperti dalil maupun rumus. Oleh sebab itu, peran pembuktian dalam matematika sangatlah penting. Bukti (proof) adalah argumen dari suatu premis ke suatu kesimpulan yang dapat meyakinkan ornag lain agar dapat menerima kesimpulan baru tersbut (Shadiq, 2014: 69).

National Council of Teachers of Mathematics (NCTM) (2000: 56) menyebutkan bahwa mathematical reasoning and proof offer powerful ways of developing and expressing insights about a wide range of phenomena. Lebih lanjut disebutkan bahwa ultimately, a mathematical proof is a formal way of expressing particular kinds of reasoning and justification. Artinya, penalaran dan pembuktian matematika menawarkan cara ampuh untuk mengembangkan dan mengekspresikan wawasan tentang berbagai fenomena. Oleh sebab itu, pembuktian matematika adalah cara formal untuk mengekspresikan berbagai fakta atau keterangan dalam penalaran dan pembenaran. Menurut Lestari dan Yudhanegara (2015: 88) kemampaun pembuktian matematis adalah kemampuan memahami pernyataan atau symbol matematika serta memberikan alas an/bukti terhadap kebenaran solusi.Pembuktian dibagi ke dalam dua jenis. Pembuktian langsung (direct proof) dan pembuktian tidak langsung (indirect proof). Sadikin (2009: 138) mengatakan bahwa bentuk pembuktian langsung di antaranya: metode pengecekan satu persatu, pembuktian dengan eliminasi kasus, dan pebuktian dengan ekuivalensi, sedangkan pembuktian tidak langsung adalah pembuktian dengan cara kontradiksi dan pembuktian dengan cara kontradiksi.

Berbagai hasil penelitian menunjukkan bahwa kemampuan siswa maupun mahasiswa dalam pembuktian matematika matematika masih tergolong lemah. Hasil penelitian di luar negeri oleh Selden \& Selden (2003), Ozdemir \& Ovez (2012) dan Guler (2016) menyimpulkan bahwa masih banyak mahasiswa yang mengalami kesulitan dalam membuktikan. Selanjutnya hasil penelitian Yerizon (2011) di Indonesia yang menyimpulkan bahwa kemampuan pembuktian matematis mahasiswa masih rendah.

Salah satu mata kuliah di semester V Program Studi Pendidikan matematika IKIP PGRI Pontianak Fakultas Pendidikan Mipatek yang memiliki tingkat abstraksi yang lumayan tinggi adalah pengantar analisis real (PAR). Selain itu, mata kulaih PAR sarat sekali dengan pembuktian. Salah satu tujuan diajarkannya pengantar analisis rela adalah agar mahasiswa mampu berpikir secara logis, deduktif, serta mampu menganalisis 
mamasalah dan mampu menyelesaikannya sehingga kemampuan mahasiswa dalam beripikir abstrak dalam matematika akan berkembang. Selanjutnya, diskripsi mata kuliah pengantar analisis real dapat dijabarkan sebagai berikut: (2) sekilas tentang aljabar himpunan (2) fungsi dan induksi matematika (3) sistem bilangan real (4) sifat aljabar bilangan real (5) sifat urutan bilangan real (6) nilai mutlak (7) sifat kelengkapan bilangan real (8) aplikasi sifat supremum (9) interval dan desimal (10) himpunan-himpunan tak hingga (11) barisan bilangan real (12) barisan bilangan real dan limitnya (13) teorema limit barisan (14) barisan monoton (15) sub-sub barisan dan teorema Bolzano-Weierstrass (16) kriteria Cauchy (17) barisan-barisan divergen.

Materi pengantar analisis PAR tergolong memiliki tingkat abstraksi yang tinggi jika dibandingkan dengan mata kuliah yang lain di semester V Program Studi Pendidikan matematika IKIP PGRI Pontianak. Selain itu, materi mata kuliah ini lumayan banyak. Oleh sebab itu, pemahaman mahasiswa terhadap mata kuliah PAR tergolong rendah. Ini dibuktikan dengan hasil UTS PAR dengan rata-rata hanya 37 yang masih diharapkan. Rendahnya nilai rata-rata UTS PAR disebakan kesalahan yang dilakukan oleh mahasiswa itu sendiri. Jika ini dibiarkan maka akan berakibat terhambatnya perkuliahan mahasiswa dan tentunya mahasiswa akan terlambat dalam menyelesaikan studinya di IKIP PGRI Pontianak. uraian tersebut mendasari perlunya sebuah analisis kesalahan mahasiswa dalam menyelesaikan soal-soal PAR dan penyebab dari kesalahan tersebut sehingga selanjutnya diharapakan mahasiswa tidak melakukan kesalahannya lagi. Selain itu, hasil penelitian ini bisa menjadi masukan bagi dosen-dosen yang lain terkait kesalahan dan penyebabnya yang dilakukan mahasiswa dalam menyelesaikan soal-soal PAR, sehingga dosen bisa memberikan antisipasi didaktis kesalahan-kesalahan yang dilakukan mahasiswa.

\section{METODE}

Penelitian ini dilaksanakan di semester V kelas C sore Program Studi Pendidikan matematika IKIP PGRI Pontianak. Teknik pengambilan sampel dilakukan dengan purposive sampling. Pengumpulan data dilakukan setelah menentukan subjek penelitian. Teknik pengumpulan data yang digunakan dalam penelitian ini yaitu wawancara berbasis tugas dimana siswa diminta untuk mengerjakan tes terlebih dahulu. Kemudian-dilakukan wawancara berbasis tugas tersebut. Subjek penelitian ini adalah 3 orang mahasiswa di kelas C sore Program Studi Pendidikan Matematika dengan kategori siswa yang memiliki hasil belajar matematika rendah, sedang, dan tinggi. Teknik analisis data yang digunakan adalah reduksi data (data reduction), penyajian data (data display), dan penarikan kesimpulan (conclusion drawing). 


\section{HASIL DAN PEMBAHASAN}

Berdasarkan hasi jawaban Ujian Akhir Semeste (UAS) diperoleh bahwa mahasiswa banyak melakukan kesalahan dalam menjawab soal-soal PAR baik mahasiswa dengan kemampuan tinggi, sedang, dan rendah. Di bawah ini akan dipaparkan secara rinci kesalahan-kesalahan yang dilakukan oleh mahasiswa yang mengerjakan soal-soal PAR seperti yang akan ditampilkan pada Gambar 1, Gambar 2, dan Gambar 3. Selanjutnya, hasil jawaban tersebut akan dikonfirmasi dengan hasil wawancara mahasiswa.

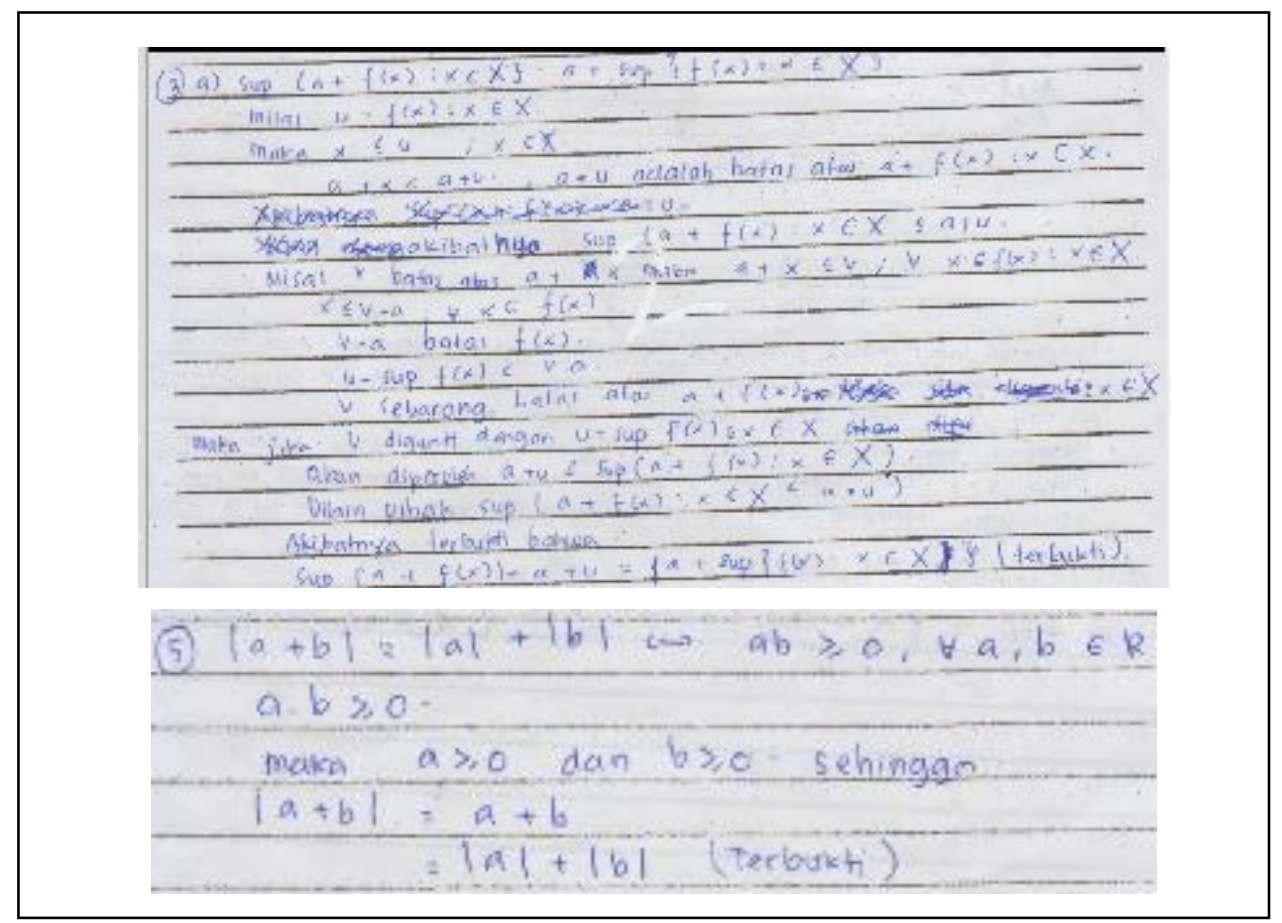

Gambar 1 Hasil Jawaban Mahasiswa dengan Kategori Tinggi

Dari hasil jawaban mahasiswa $\left(\mathrm{P}_{1}\right)$ dengan kategori tinggi pada Gambar 1 soal 3 dapat dilihat bahwa mahasiswa melakukan kesalahan dalam menempatkan tanda pertidaksamaan $\leq$ (kurang atau sama dengan) seperti jawaban soal no 3 misal $u=f(x)$ maka $x \leq u$, padahal $x$ adalah anggota $f(x)$ jadi seharusnya $x$ anggota $u$. Tetapi, walaupun $\mathrm{P}_{1}$ benar dalam menyimpulkan bahwa $x$ anggota $\mathrm{u}, \mathrm{P}_{1}$ juga tidak mungkin membuktikan apa yang diminta oleh soal. Jika dilihat dari jawaban tersebut, $P_{1}$ salah dalam mengambil pemisalan. Seandaninya $P_{1}$ memisalkan $u$ adalah supremum dari $f(x), \forall x \in X$ maka $x \leq u$ sehingga $a+x \leq a+u, \forall a+u \in a+f(x)$. Dengan demikian, benar jika disimpulkan bahwa $a+u$ adalah batas atas dari $a+f(x)$. Selain itu, $P_{1}$ dalam menjawab soal tidak diawali dengan kata "akan dibuktikan" atau "bukti" sehingga jawaban $\mathrm{P}_{1}$ tidak terstruktur dengan baik. Berdasarkan hal-hal di atas, diduga bahwa mahasiswa masih bingung untuk memulai pembuktian, $P_{1}$ juga tidak memahami teorema tersebut walapun $P_{1}$ sudah memahami konsep atau definisi dari supremum dan infimum. Berdasarkan hasil wawancara, 
mahasiswa masih kebingungan untuk memulai dalam pembuktian karena $P_{1}$ juga bingung untuk membuktikan yang ada tanda persamaannya. Selanjutnya, $P_{1}$ juga tidak memahami teorema yang diminta untuk dibuktikan.

Hasil jawaban pada soal 5 , siswa $\mathrm{P}_{1}$ melakukan kesalahan dalam menjawab soal tersebut. Kesalahan yang dilakukan oleh $\mathrm{P}_{1}$ adalah membuktikan biimplikasi hanya dalam satu arah dan itupun hanya arah ke kiri, pembuktian biimplikasi yang arah ke kiri pun masih salah. Jika $a . b \geq 0$ tidak bisa kita simpulkan bahwa $a \geq 0$ dan $b \geq 0$ karena a. $b \geq 0$ bisa terjadi dua kemungkinan a dan positif atau a dan b negatif. Sebagaimana jawaban no 3, jawaban $\mathrm{P}_{1}$ pada soal no 5 kurang terstruktur dan alangkah baiknya sebelum membuktikan suatu teorema mapun pernyataan ada kata "akan dibuktikan" atau "bukti". Adapun kesalahan yang dilakukan oleh $\mathrm{P}_{1}$ diduga $\mathrm{P}_{1}$ tidak memahami konsep biimplikasi dan memahasi konsep niali mutlak. Berdasarkan hasil analisis wawancara, $\mathrm{P}_{1}$ memahami konsep biimplikasi tetapi pada saat menjawab soal kurang teliti, $\mathrm{P}_{1}$ memahami bahwa jika biimplikasi harus dibuktikan dengan dua arah, tetapi $P_{1}$ tidak memahami teorema yang harus dibuktikan karena $P_{1}$ jarang sekali memecahkan masalah yang besifat deduktif aksiomatif atau masalah-masalah yang memiliki tingkat kesulitan tinggi.

Adapun penyebab kesalahan mahasiswa dengan kategori tinggi ini adalah sebagai berikut: kurang teliti dalam melakukan pembuktian, terburu-buru dalam menyelesaikan soal, jarang menyelesaikan soal-soal yang memiliki kesulitan tingkat tinggi atau soal-soal high order thinking, mahasiswa lemah dalam kemampaun pembuktian matematis, dan mahasiswa juga tidak terbiasa dalam menajwab soal dengan pola yang terstruktur. Dengan demikian, dapat dikatakan bahwa untuk subjek pertama dengan kategori siswa tinggi: kesalahan yang yang dilakukan oleh mahasiswa adalah salah dalam memberikan pemisalan, salah memberikan kesimpulan di langkah-langkah jawaban, tidak memahami teorema yang harus dibuktikan. Berdasarkan kesalahan-kesalahan tersebut disebabkan oleh mahasiswa kurang teliti dalam melakukan pembuktian, terburu-buru dalam menyelesaikan soal, jarang menyelesaikan soal-soal yang memiliki kesulitan tingkat tinggi atau soal-soal high order thinking, mahasiswa lemah dalam kemampaun pembuktian matematis, dan mahasiswa juga tidak terbiasa dalam menajwab soal dengan pola yang terstruktur.

Berikut disajikan hasil pekerjaan subjek dengan kemampuan sedang $\left(\mathrm{P}_{2}\right)$ 


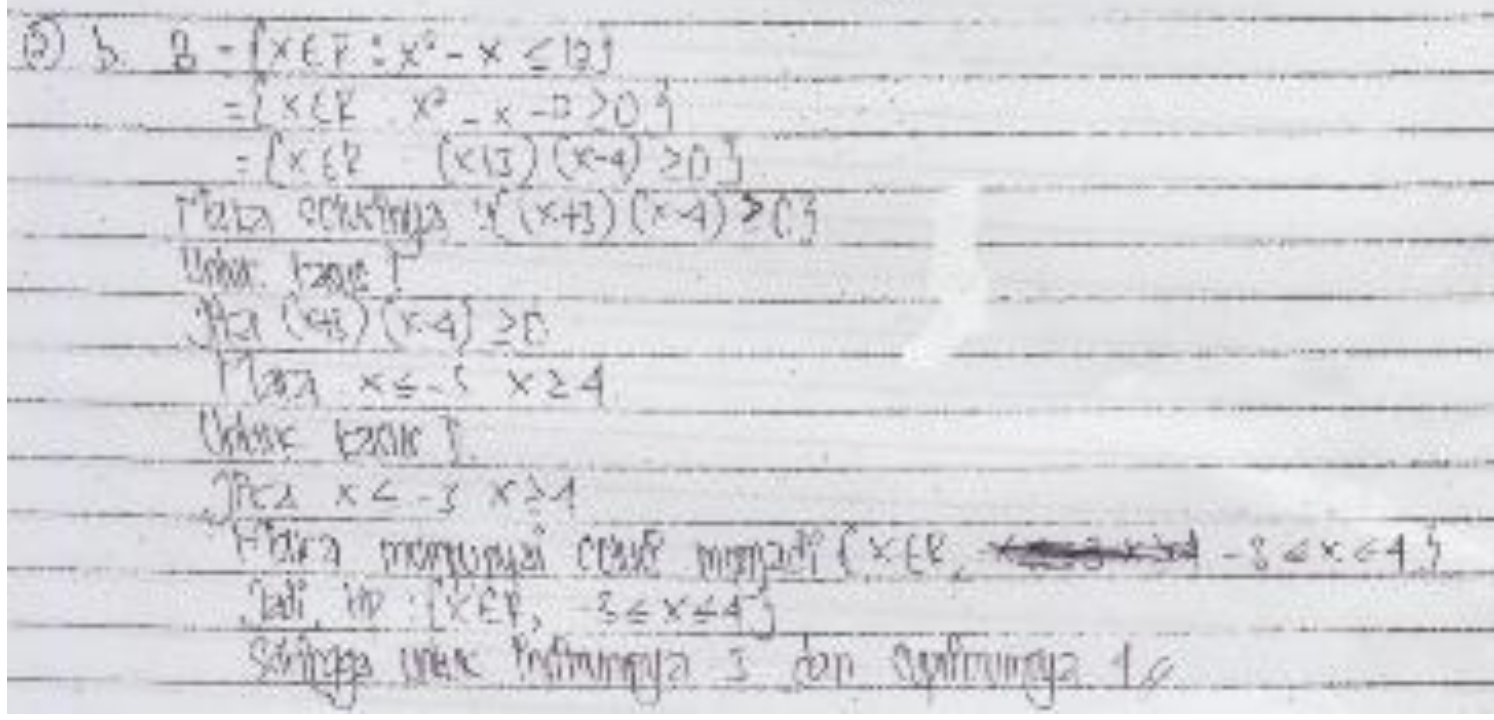

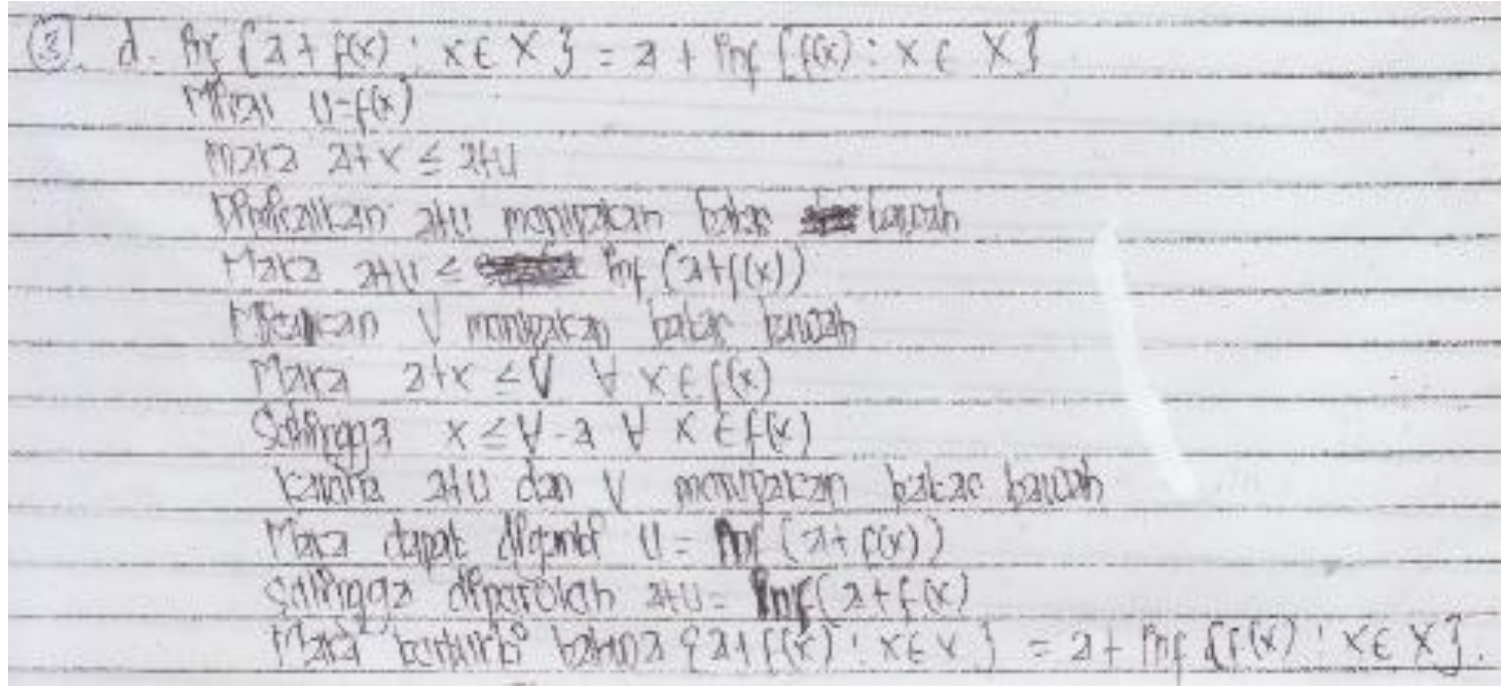

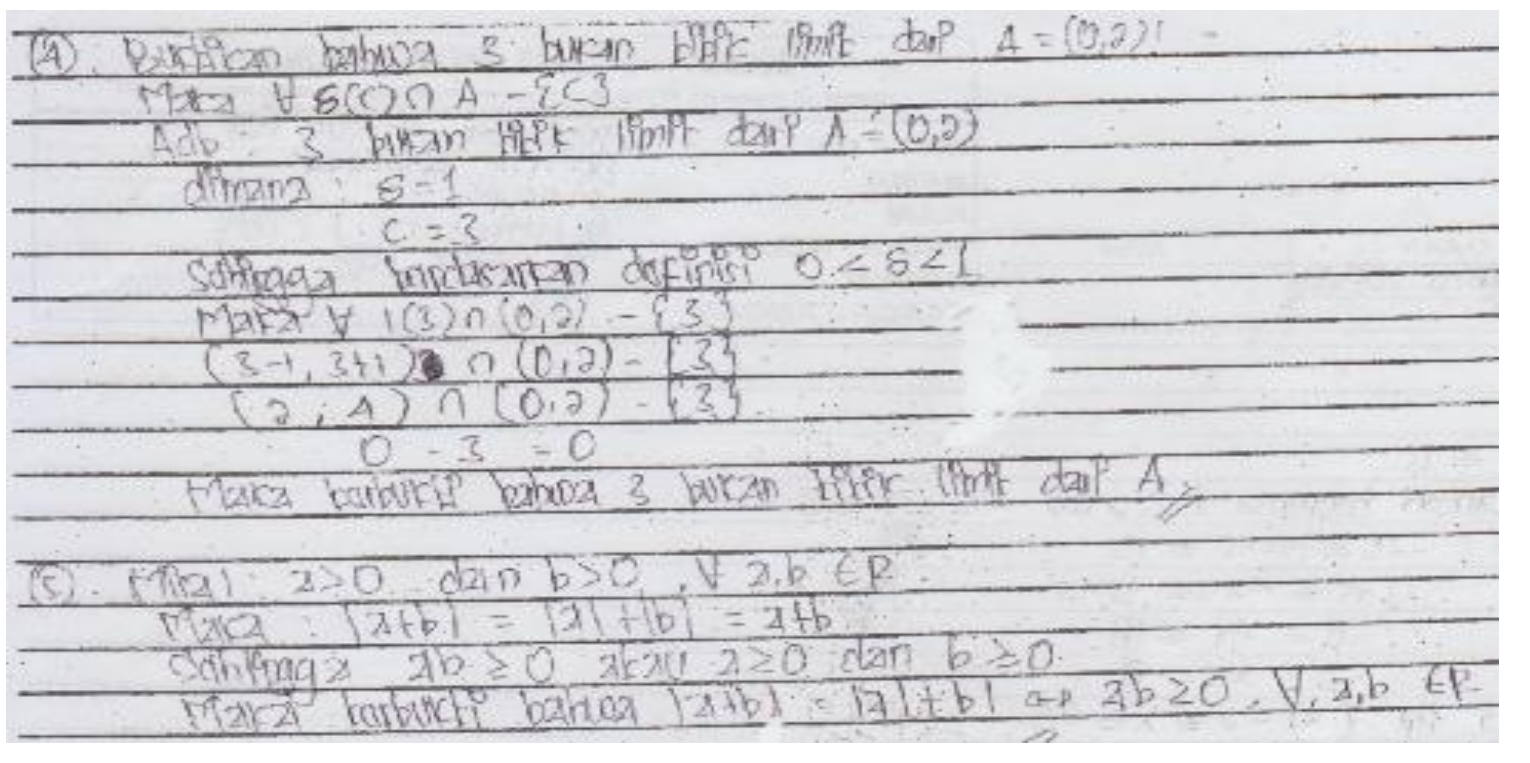

Gambar 2. Hasil Jawaban Mahasiswa dengan Kategori Sedang 
Berdasarkan hasil jawaban mahasiswa $\left(\mathrm{P}_{2}\right)$ dengan kategori sedang sebagaimana disajikan pada Gambar 2 dapat dilihat bahwa siswa melakukan kesalahan dalam operasi bilangan bulat dan penggunaan tanda pertidaksamaan seperti pada soal no 2 di mana $x^{2}-x \leq 12$ menjadi $x^{2}-x-2 \geq 0$ sehingga kesalahan yang dilakukan mahasiswa adalah hasil operasi bilangan bulat dari 12 menjadi -2 dan $\leq$. Selain itu, pada no 2 mahasiswa menjawab bahwa himpunan penyelesaian dari $(x+3)(x-4) \geq 0$ menjadi dua kasus tetapi dua kasus tersebut sama yaitu: $x \leq-3$ dan $x \geq 4$. Dari kesalahan tersebut, diduga mahasiswa tidak teliti dalam mengerjakan soal dan tidak memahami konsep pertidaksamaan kuadrat. Tetapi, berdasarkan hasil wawancara mahasiswa $\mathrm{P}_{2}$ memahami konsep pertidaksamaan kuadrat, tetapi mahasiswa tersebut kurang teliti dalam mengerjakan soal yang diberikan. Temuan ini didukung oleh temuan Mustikasari, dkk. (2010: 58) bahwa siswa kurang teliti dalam mengerjakan soal sehingga melakukan kesalahan dalam proses perhitungan.

Selanjutnya bedasarkan hasil jawaban soal no 3 dapat dilihat pada Gambar 2 bahwa mahasiswa melakukan kesalahan yang hampir sama dengan apa yang dilakukan oleh mahasiswa dengan kategori tinggi $\left(P_{1}\right)$. Mahasiswa $P_{2}$ melakukan kesalahan dalam menempatkan tanda pertidaksamaan $\leq$ (kurang atau sama dengan) seperti jawaban soal no 3 misal $u=f(x)$ maka $a+x \leq a+u$, padahal $x$ adalah anggota $f(x)$ jadi seharusnya $x$ anggota $u$. Selain itu, $P_{2}$ juga melakukan kesalahan dengan memisalkan bahwa $a+x$ adalah batas bawah sehingga $a+x \leq \inf (a+f(x))$. Selain itu, $P_{2}$ dalam menjawab soal tidak diawali dengan kata "akan dibuktikan" atau "bukti" sehingga jawaban $\mathrm{P}_{2}$ tidak terstruktur dengan baik sebagaimana jawaban dari $\mathrm{P}_{1}$. Adapun kesalahan-kesalahan yang dilakukan oleh $\mathrm{P}_{2}$, diduga mahasiswa masih bingung untuk memulai pembuktian, $\mathrm{P}_{1}$ juga tidak memahami teorema tersebut walapun $\mathrm{P}_{1}$ sudah memahami konsep atau definisi dari supremum dan infimum. Berdasarkan hasil wawancara, mahasiswa masih kebingungan untuk memulai dalam pembuktian karena $\mathrm{P}_{2}$ juga bingung untuk membuktikan yang ada tanda persamaannya. Selanjutnya, $\mathrm{P}_{2}$ juga tidak memahami teorema yang diminta untuk dibuktikan karena jarang mengerjakan soal yang berkaitan dengan kemampuan pembuktian matematis.

Dari jawaban soal no 4, mahasiswa tidak terstruktur dalam menjawab soal. Selanjutnya, jika ingin membuktikan bahwa 3 bukan titik limit dari $A=(0,2)$, tentunya mahasiswa harus memilih $\delta$ sehingga terbukti bahwa dengan dipilihnya $\delta$ terbukti bahwa hasilnya adalah himpunan kosong. Tetapi, dari jawaban tersebut mahasiswa mengatakan "di mana $\delta=1$ ". Kemudian kesalahan berikutnya adalah hasil operasi himpunan di mana $(2,4) \cap(0,2)=0$. Seharusnya himpunan kosong tidak ditulis dengan 0 , tetapi ditulis 
dengan \{\} atau $\emptyset$. Berdasarkan kesalahan-kesalahan tersebut, diduga mahasiswa tidak memahami konsep himpunan dan tidak memahami cara memberikan penyangkal bahwa 3 bukan titik limit dari $A=(0,2)$. Berdasarkan hasil wawancara, mahasiswa tidak memahami simbol dari himpunan kosong dan mahasiswa juga tidak memahami cara memberikan penyangkan jika diminta untuk membuktikan bahwa 3 bukan titik limit dari A.

Selanjutnya dari jawaban no 5 , mahasiswa $\mathrm{P}_{2}$ melakukan kesalahan sebagaimana dilakukan oleh $\mathrm{P}_{1}$. Kesalahan yang dilakukan oleh $\mathrm{P}_{2}$ adalah membuktikan biimplikasi hanya dalam satu arah dan itupun hanya arah ke kiri, pembuktian biimplikasi yang arah ke kiri pun masih salah. Jika a.b $\geq 0$ tidak bisa kita simpulkan bahwa $a \geq 0$ dan $b \geq 0$ karena $a . b \geq 0$ bisa terjadi dua kemungkinan a dan positif atau a dan $b$ negatif. Adapun kesalahan yang dilakukan oleh $\mathrm{P}_{2}$ diduga $\mathrm{P}_{2}$ tidak memahami konsep biimplikasi dan memahasi konsep niali mutlak. Berdasarkan hasil analisis wawancara, $P_{2}$ memahami konsep biimplikasi tetapi pada saat menjawab soal kurang teliti, $P_{2}$ memahami bahwa jika biimplikasi harus dibuktikan dengan dua arah, tetapi $\mathrm{P}_{2}$ tidak memahami teorema yang harus dibuktikan karena $P_{2}$ jarang sekali memecahkan masalah yang besifat deduktif aksiomatif atau masalah-masalah yang memiliki tingkat kesulitan tinggi.

Dengan demikian, dapat dikatakan bahwa untuk subjek kedua dengan kategori siswa sedang: kesalahan yang dilakukan oleh mahasiswa adalah salah dalam mengoperasikan bilangan bulat dan himpunan penyelesaian pertidaksamaan kuadrat, salah dalam memberikan pemisalan, salah memberikan kesimpulan di langkah-langkah jawaban, tidak memahami teorema yang harus dibuktikan. Berdasarkan kesalahan-kesalahan tersebut disebabkan oleh mahasiswa kurang teliti dalam melakukan pembuktian, terburu-buru dalam menyelesaikan soal, jarang menyelesaikan soal-soal yang memiliki kesulitan tingkat tinggi atau soal-soal high order thinking, mahasiswa lemah dalam kemampaun pembuktian matematis, dan mahasiswa juga tidak terbiasa dalam menajwab soal dengan pola yang terstruktur.

Berikut disajikan hasil pekerjaan mahasiswa dengan kategori rendah $\left(\mathrm{P}_{3}\right)$ 


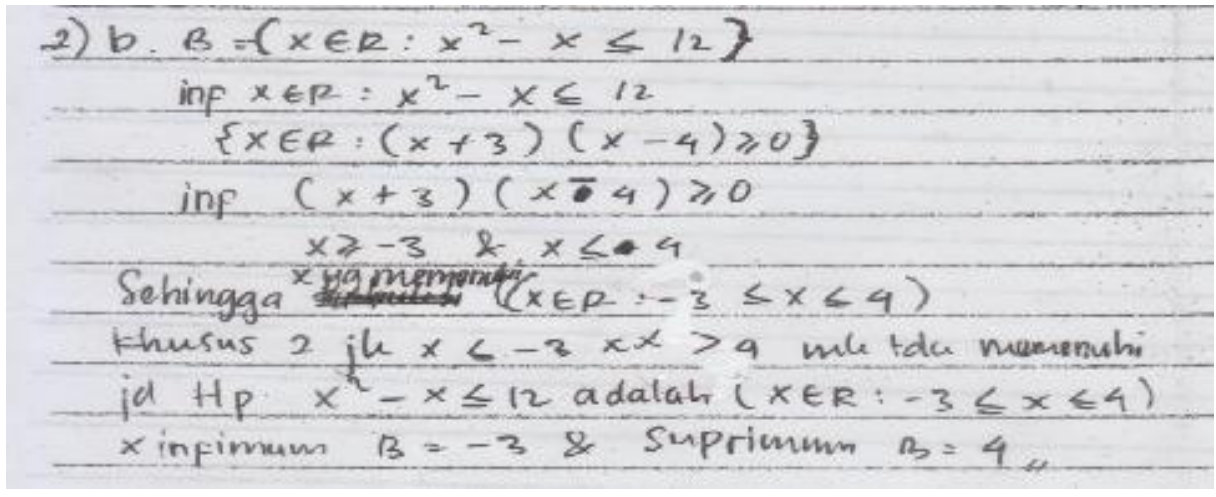

3) $\operatorname{Inf}\{a+f(x): x \in x\}=a+\inf \{f(x): x \in x\}$ rede

$\rightarrow$ jika inf $\{a+f(x): x \in x\}=a+\ln _{f}\left\{f(x): x \in x^{3}\right.$ malea $\inf (a+f(x)=a+i f f(f(x))$ sehingga $(a+f(x)=a+(f(x)) \rightarrow$ sama. twi hation bahwa dari hasil diatas menunjalkian bahwa terbaleti tidale mempanyai range yang turbatas didalam $R \rightarrow$ atan $a \in R:(a+f(x)$

4) $A=(0,2)$ dan $A(\delta=3)$ misal. Bardavarlaan $\delta$ Climit yg artinga mendeleati / fitile yg mendeleati. maka akan lita buletilean melalui kurva / gatis lurva

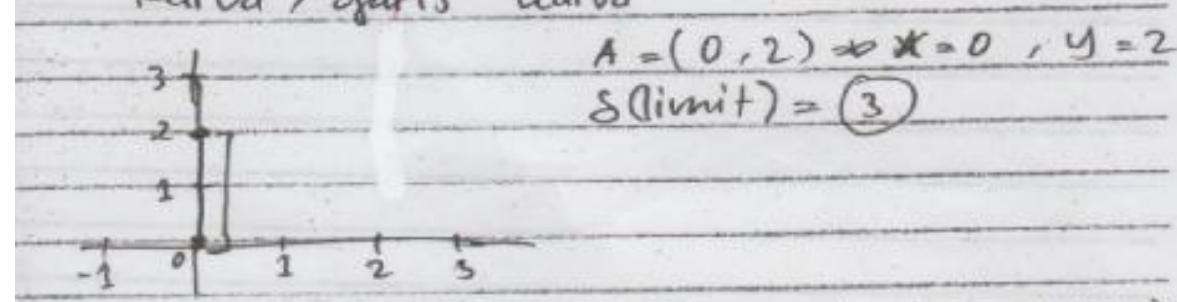

Berdasarkan gambar disampi atas menunjuch kan bahwa 3 hulean titile limit

5) $|a+b|=|a|+|b| \leftrightarrow a b \geqslant 0, \forall r a, b \in R !$

* $|a+b|=|a|+|b|$ jk $a>0$ \& $b>0$, sehingga

$|a+b|=a+b=|a|+|b| j k \quad a>0 \& b<0$ maka $|a+b|<0$ sehingga $|a+b|=a+(-b)=|a|+|-b|$ $=|a|+|b|$ 
Hasil jawaban mahasiswa $\left(\mathrm{P}_{3}\right)$ dengan kategori rendah pada Gambar 3 no 2 dapat dilihat bahwa mahasiswa melakukan kesalahan dalam menentukan infimum dan suremum dari $x^{2}-x \leq 12, x \in R$. Mahasiswa menuliskan bahwa inf $x \in R=x^{2}-x \leq 12$ kemudian $\mathrm{P}_{3}$ juga melakukan kesalahan dengan merubah $x^{2}-x \leq 12$ menajadi $(x+3)(x-4) \geq 0$. Oleh sebab itu, diduga kesalahan yang dilakukan oleh $\mathrm{P}_{3}$ dikarenakan mahasiswa tersebut tidak memahami konsep pertidaksamaan kuadrat dan tidak memahami konsep infimum dan supremum. Selanjutnya, berdasarkan hasil wawancara dengan mahasiswa diperoleh bahwa mahasiswa kurang memahami konsep pertidaksamaan kuadrat dan tidak memahami konsep infimum dan supremum.

Dari jawaban soal no 3, mahasiswa melakukan kesalahan sebagaimana yang dilakukan oleh mahasiswa dengan kategori sedang. Mahasiswa $P_{3}$ salah dalam menyimpulkan konsep yang diberikan seperti dilihat dari jawaban $P_{3}$ jika $\inf (a+f(x) ; x \in X)=a+\inf \{f(x) ; x \in X\}$ maka $\inf (a+f(x) ; x \in X)=a+\inf \{f(x) ; x \in X\} \quad$ sehingga $a+f(x)=a+f(x)$. Kesimpulkan $a+f(x)=a+f(x)$ tidak dasar dan tidak ada aksioma maupun teorema yang menjamin dari kebenaran dari kesimpulan tersebut. Penyebabnya diduga karena mahasiswa tidak memahami teorema tersebut dan konsep infimum dan supremum. Hasil dugaan ini diperkuat dengan hasil wawancara, ternyata mahasiswa $\mathrm{P}_{3}$ tidak memahami teorema dan konsep infimum dan supremum.

Selanjutnya berdasarkan jawaban soal no 4, mahasiswa tidak memahami konsep titik limit atau definisi dari titik limit. Mahasiwa $P_{3}$ membuktikan titik limit dengan menggunakan garis/kurva, sehingga jawabannya tidak jelas arahnya. Dari soal tersebut, diminta untuk membuktikan bahwa 3 bukan titik limit dari $A=(0,2)$, tetapi $P_{3}$ ingin membuktikan bahwa 3 adalah titik limit dari $A$ jadi $P_{3}$ tidak memahami betul apa yang ditanyakan oleh soal. Kesalahan ini diduga mahasiswa tidak memahami konsep titik limit dan terburu-buru dalam mengerjakan soal. Dari hasil wawancara, dan ternayata $\mathrm{P}_{3}$ tidak memahami konsep titik limit.

Selanjutnya dari jawaban no 5 , mahasiswa $P_{3}$ melakukan kesalahan sebagaimana dilakukan oleh $P_{1}$ dan $P_{2}$. Kesalahan yang dilakukan oleh $P_{3}$ adalah membuktikan biimplikasi hanya dalam satu arah dan itupun hanya arah ke kiri, pembuktian biimplikasi yang arah ke kiri pun masih salah, tidak jelas alur berpikirnya. Kesimpulan dari mahasiswa bahwa $a>0$ dan $\mathrm{b}<0 \rightarrow|a+b|<0$ sehingga $|a+b|=a+(-b)=|a|+|-b|=|a|+|b|$ benar, tetapi $a>0$ dan $\mathrm{b}<0 \rightarrow \mathrm{ab}<0$ padahal di soal sudah disebutkan bahwa $a b \geq 0$. Adapun kesalahan yang dilakukan oleh 
$P_{3}$ diduga $P_{3}$ tidak memahami konsep biimplikasi dan memahasi konsep nilai mutlak. Berdasarkan hasil analisis wawancara, $\mathrm{P}_{3}$ memahami konsep biimplikasi tetapi pada saat menjawab soal kurang teliti, $\mathrm{P}_{3}$ memahami bahwa jika biimplikasi harus dibuktikan dengan dua arah, tetapi $P_{3}$ tidak memahami teorema yang harus dibuktikan karena $P_{3}$ jarang sekali memecahkan masalah yang besifat deduktif aksiomatif atau masalah-masalah yang memiliki tingkat kesulitan tinggi. Oleh sebab itu, dapat disimpulkan bahwa mahasiswa dengan kategori rendah melakukan kesalahan dalam: menentukan infimum dan suremum, menyelesaikan pertidaksamaan kuadrat, kesalahan dalam memberikan kesimpulan dari langkah pembuktian yang diberikan, kesalahan dalam menentukan titik limit, kesalahan dalam pembuktian yang berupa bimplikasi dan memberikan kesimpulan yang salah dalam biimplikasi. Adapun penyebab dari kesalahan tersebut adalah: kurang memahami konsep pertidaksamaan kuadrat dan tidak memahami konsep infimum dan supremum, tidak memahami teorema dan konsep infimum dan supremum, tidak memahami konsep titik limit, dan tidak memahami teorema yang harus dibuktikan karena $P_{3}$ jarang sekali memecahkan masalah yang besifat deduktif aksiomatif atau masalah-masalah yang memiliki tingkat kesulitan tinggi.

\section{SIMPULAN}

Kesalahan yang dilakukan oleh mahasiswa dengan kategori tinggi pada kelas $\mathrm{C}$ sore semester V Program Studi Pendidikan matematika IKIP PGRI Pontianak Fakultas Pendidikan MIPATEK dalam mengerjakan soal pengantar analisis real (PAR) adalah: kesalahan yang yang dilakukan oleh mahasiswa adalah salah dalam memberikan pemisalan, salah memberikan kesimpulan di langkah-langkah jawaban, tidak memahami teorema yang harus dibuktikan. Kesalahan yang dilakukan mahasiswa dengan kategori sedang adalah: salah dalam mengoperasikan bilangan bulat dan himpunan penyelesaian pertidaksamaan kuadrat, salam memberikan pemisalan, salah memberikan kesimpulan di langkah-langkah jawaban, tidak memahami teorema yang harus dibuktikan. Kesalahan yang dilakukan mahasiswa dengan kategori rendah adalah: salah menentukan infimum dan suremum, salah menyelesaikan pertidaksamaan kuadrat, kesalahan dalam memberikan kesimpulan dari langkah pembuktian yang diberikan, kesalahan dalam menentukan titik limit, kesalahan dalam pembuktian yang berupa bimplikasi dan memberikan kesimpulan yang salah dalam biimplikasi.

Faktor penyebab kesalahan mahasiwa dengan kategori tinggi dan sedang dalam mengerjakan soal-soal PAR adalah: mahasiswa kurang teliti dalam melakukan pembuktian, terburu-buru dalam menyelesaikan soal, jarang menyelesaikan soal-soal yang memiliki kesulitan tingkat tinggi atau soal-soal high order thinking, mahasiswa lemah dalam kemampaun pembuktian matematis, dan mahasiswa juga tidak terbiasa dalam menajwab 
soal dengan pola yang terstruktur. Faktor penyebab kesalahan mahasiswa dengan kategori rendah adalah: kurang memahami konsep pertidaksamaan kuadrat dan tidak memahami konsep infimum dan supremum, tidak memahami teorema dan konsep infimum dan supremum, tidak memahami konsep titik limit, dan tidak memahami teorema yang harus dibuktikan karena $P_{3}$ jarang sekali memecahkan masalah yang besifat deduktif aksiomatif atau masalah-masalah yang memiliki tingkat kesulitan tinggi.

\section{DAFTAR PUSTAKA}

Guler, G. 2016. The Difficulties Experienced in Teaching Proof to Prospective Mathematics Teachers: Academician View Higher Education Studies. Vol. 6, No. 1. 145-158.

Lestari, K. E. dan Yudhanegara, M. R. 2015. Penelitian Pendidikan Matematika. Bandung: PT Refika Aditama.

Mustikasari. Zulkardi. \& Aisyah, N. 2010.Pengembangan Soal-Soal Open-Ended Pokok Bahasan Bilangan Pecahan di Sekolah Menengah Pertama. Jurnal Pendidikan Matematika, Volume 4. No.1. 45-60.

NCTM. 2000. Principles and Standards for School Mathematics. The United State of America.

Ozdemir, E. \& Ovez, F. T. D. 2012. A Research On Proof Perceptions And Attitudes Towards Proof And Proving: Some Implications For Elementary Mathematics Prospective Teachers. Procedia - Social and Behavioral Sciences 46. 2121 - 2125

Sadikin, A. 2009. Pengantar Logika Matematika dan Himpunan. Pontianak: STAIN Pontianak Press.

Selden, A \& Selden, T. 2003. Validations of Proofs Considered as Texts: Can Undergraduates Tell Whether an Argument Proves a Theorem? Journal for Research in Mathematics Education, Vol. 34, No. 14-36.

Shadiq, F. 2014. Pembelajaran Mateatika Cara Meningkatkan Kemampuan Berpikir Siswa. Yogyakarta: Graha IImu.

Yerizon. 2011. Peningkatan Kemampuan Pembuktian Dan Kemandirian Belajar Matematik Mahasiswa Melalui Pendekatan M-Apos. Disertasi UPI Bandung. Tidak Diterbitkan. 